\title{
POEMS AS LIVABLE WORLDS: A CONVERSATION WITH AFSHAN D'SOUZA-LODHI AND JAY BERNARD
}

Sometimes the best projects emerge out of serendipitous encounters. It was, indeed, serendipity which allows us to bring you the following conversation. Recorded involuntarily and transcribed thoroughly, the following text is a testimony of an encounter between poets Afshan D'souza-Lodhi and Jay Bernard and a community of scholars and students, during a time when gatherings in rooms were not marked by the laws of social distancing. During our conversation, Jay and Afshan speak to us about languages and mother tongues, queer identities, love and desire, activisms and the archive, affect, politics and the role of literature. Through their answers, as well as the poems that accompany them, we become witnesses to the power of words to create alternative realities, ones that are more livable, gentle and embracing of nonnormativity.

Afshan D'souza-Lodhi is a queer Muslim writer born in Dubai to Indian and Pakistani parents and currently living in Manchester. She writes theatre and poetry, as well as non-fiction, and works with young and emerging artists. Together with her work as an artist - she's been a resident at the Royal Exchange Theatre and the Manchester Literature Festival, and has worked with Eclipse Theatre, Tamasha Theatre Company and Paul Burston's Polari- Afshan is a member of Northern Police Monitoring Project, an independent campaigning and advocacy organization that challenges police harassment and violence.

Afshan's work centres on the experience of women of South Asian heritage, be it in the context of the Indo-Pakistani Partition in the theatre piece Santi \& Naz (2020, The Vault), or the everyday life in an all-female-run halal butcher shop in the radio play Chop Chop (2019, BBC Radio). In her short play Lesborist Tapes (2015) -later made into a short film for Channel 4 called An Act of Terror (2018) - Afshan dismantles the trope of the Muslim terrorist against the idea of sexually terrorizing the West and explores the relationship between capitalism, patriarchy, religion and sexuality in the context of the War on Terror. Her short essay "Hijabi (R)evolution" was included in the collection It's Not About the Burqa (2019), and in it Afshan reflects upon her own relationship with Islam and the Hijab as a young queer Muslim growing up in the West, in a context of growing Islamophobia. Her latest poetry collection,

Massana, Elisabeth and Cristina Alsina Rísquez (2020), "Poems as Livable Worlds: A Conversation with Afshan D'souza-Lodhi and Jay Bernard", Lectora, 26: 223-246. ISSN: 1136-5781, D.O.I.:10.1344/Lectora2020.26.24, emassana@ub.edu, alsina@ub.edu 
[re:desire] (2020) published by Burning Eye Books, explores love, desire, Muslim queerness, the relationship between mothers, daughters and mother tongues, abuse and racism from a South Asian perspective. Her poems are both a celebration of Desi culture and a testimony of its clashes with Britishness.

Jay Bernard, born and raised in Croydon, is a poet and performance artist resident in London. Together with their writing, they work as programmer for BFI Flare, the London LGBTIQ+ Film Festival, they are co-editor of the literary magazine Oxford Poetry and since 2018, a fellow of the Royal Society of Literature. Jay's work has been featured in several anthologies, amongst which the recent New Daughters of Africa (2019). Their work investigates the ramifications of history and the role of the archive in the construction of black and queer identities. Their poetry pamphlet The Red and Yellow Nothing (2016) is an exploration of the presence, and specially lack thereof, of blackness in the European literary canon through imaginatively writing a prequel to "Morien" a Middle-Dutch poem and one of the episodes of the Arthurian legends. Jay was the first Poet-in-Residence at the George Padmore Institute in 2016, a library, archive and educational research centre set up in 1991 by New Beacon Books, which houses materials relative to the life and experiences of Caribbean, African and Asian communities in the UK. Jay's work as an archivist was fundamental for the development of their multimedia performance work Surge: Side A for which they won the 2017 Ted Hughes Award for new poetry. The poems were featured in the collaborative text Beacon of Hope: New Beacon in Poetry and Prose (2016), a commemorative book celebrating the 50th Anniversary of the bookstore and publishing house New Beacon Books, founded in 1966 by John La Rose and Sarah White as the first independent publisher for Black and Caribbean literature and nonfiction in Britain.

Jay's work was later developed into their latest collection, Surge (2019). In the context of the Grenfell fire, and based on the material found in the George Padmore Institute archive, the poetry collection explores the affective and political ramifications of the New Cross Fire of 1981 where fourteen young black people lost their lives. Protests following the fire, known as Black's People Day of Action, gave way to retaliation in the form of the police operation SWAMP 81, during which countless numbers of black people were stopped and searched in South London. Shortly afterwards the Brixton riots took place. Jay's poetry in Surge offers an insight into the lives lost during the fire, but also establishes an affective link between New Cross and Grenfell, between SWAMP 81 and Brexit and between the Windrush scandal and the histories of white supremacy in Britain, looking at the archive not only as a testimony of the past, but as a mirror of the present.

The presence of Jay Bernard and Afshan D'souza-Lohdi in Barcelona was facilitated by the work of Speaking Volumes, a literature organization based in the UK and founded in 2010 by Sharmilla Beezmohun and Sarah Sanders, that specializes in 
the representation of writers of colour with the aim to address and redress the lack of diversity in the publishing industry and the will to fight for racial equality in the arts. The conversation that follows took place during the 2019 Poetry Week of Barcelona, and doubled as one of the closing sessions of the 2018-2019 academic year of the master's degree Construction and Representation of Cultural Identities (Universitat de Barcelona). Both Jay and Afshan also participated in the festival with a public reading of their poems, which we include at the end of the conversation, together with their translation into Catalan.

We would like to thank Sharmilla Beezmohun for being instrumental in the organization of the event, Martí Sales for generously agreeing to the publication of his translations of the poems, Francesco Ardolino for his work during the organization of the event, as well as for involuntarily recording the session which we are now able to share with you, and Marina Bernardo for her meticulous work transcribing the text.

ELISABETH MASSANA

CRISTINA ALSINA RÍSQUEZ

Universitat de Barcelona

Cristina Alsina Rísquez: How do you conceive the role of literature in society? Do you think it can work as a tool to create safe spaces?

In relation to that, we have seen in the last few years the publication of at least five anthologies, including It's Not About the Burqa (2019) and New Daughters of Africa (2019) - that feature your work-, The Good Immigrant - both in the UK (2016) and the US (2019)-, Nepantla: An Anthology for Queer Poets of Color (2018) and Halal If You Hear Me (2019), that seem to understand the role of the anthology as that of creating community. We wanted to know what your thoughts on that are.

And as a follow up from that, we were wondering what kind of readership these anthologies invite. Each generation seems to need a new anthology to find their own identity reflected on it. Each generation celebrates their anthology as foundational. Still these anthologies have existed for some time, if we think, in particular, about the number of queer writing anthologies published in the last few years or the fact that New Daughters of Africa is an update of the original Daughters of Africa (1992). Is this identification with one particular anthology the result of their being substantially different or of the fact that, somehow, we're not managing to bridge the generational gap?

Afshan D'souza-Lodhi: So for me literature is like a historical... it's a tool that we can understand history with and that's what I've often used it as. Junot Díaz talks 
about children, sorry, Junot Díaz talks about monsters not having reflections, and children not having reflections, and being seen as monsters... so that if you're not seeing yourself in literature, you're not seeing yourself on TV or on film, you don't see yourself reflected, you end up identifying with a monster. By creating anthologies, and by writing diverse stories from all paths of life, I feel that we're creating a history, so that ten, twenty years down the line there will be a lot of different nuanced mirrors that we can see ourselves in. We never ask this question about white, straight men and their anthologies. Nobody says: "Oh, you know, there was a white straight anthology done twenty years ago. Are you sure you want to do one right now?" or "There was one done last week. Are you sure you want to do one now?" [laughter]. But suddenly, as people of colour, as women, as queer people... we suddenly have to justify that this is completely different to what has happened before. And what I'm really eager and keen to do is writing nuanced stories that might not be vastly different from what has already come, but acknowledging what has already come and kind of going, "well, here's another way of saying... Here's a poetic, here's a pretty way of saying it". And I like to think that some of my work isn't just about identity. It's about the poetry and the words, what they make you feel, that they make you laugh or cry, that they present a perspective that you perhaps haven't really seen before.

Jay Bernard: For me the anthology is a historical marker, an indication of where things were at when it was published. I think this indication can be read as much between the lines as in the explicit purpose of the text outlined in the blurb. To give a really concrete example, I think of something like The Heart of The Race: Black Women's Lives in Britain (1985), which was a collection from the 80s I came across when I was 20 or so. I had no idea what it was, but it was really -I don't want to say seminal [laughter] - but it was very important at the time, and it crystallised a lot of ideas. The Heart of the Race ${ }^{1}$ has since been revisited in London, with lots of events featuring original contributors and newer readers, writers and activists. We can also see this with queer people of colour. The first black gay male anthology was a book called Tongues Untied (1987), and for years, decades even, it was never really surpassed. That's why I think an anthology is an indicator of where we are: it takes so much time and resources to create them, and that is usually the sign of the resources in a particular community. And then weird things happen, too. Chris Soto edited Nepantla, An Anthology for Queer Poets of Color (2018), and then he got into lots of hot water when he was set to edit a special issue of Poetry Magazine. I mention this because a whole critical movement emerged called \#beyondspecialissue, showing the

\footnotetext{
${ }^{1}$ A new edition of The Heart of the Race was published in 2018 by Verso Books, including a foreword by Lola Okolosie and an interview with the authors by Heidi Safia Mirza, where they discuss the impact and continuing relevance of the book since its original publication by Virago Press in 1985.
}

226

Lectora, 26 (2020): 223-246. ISSN: 1136-5781 D.O.I.: 10.1344/Lectora2020.26.24 
ways in which trans and gender non-conforming poets were ghettoised in "special issues". Chris Soto also made an unwise comment about trans people only writing about trans things. So you can see how things got complicated... I think that the politics and production issues around anthologies, collections, special issues, are a good indicator of the work yet to be done within a community, and between that community and the mainstream.

ADL: I think we sometimes see an anthology like It's Not About the Burqa and we peek through and there will be an index at the back which will be like "these are all the identity markers, what page can I find the story that correlates to that?" And sometimes we want to write outside of that and having that marker can stop us. And I think it's about looking at anthologies as not a textbook, but as a text, as literature, to kind of move away from this learning experience. I often think that when I have conversations with people who want me to teach them about my experiences, which is really difficult because it's like "I don't wanna teach my stuff" and I leave the room sometimes. But often it's more like "Tell me more about your experiences being Muslim and about your experiences being queer", please educate me on all these things that they can really google, and read the many anthologies that are out there; it is not really up to us to teach and so the anthology can sometimes help to move away from that.

CA: That's a good point actually. I hadn't thought of the anthology as a textbook, and the good and bad things about it, because then we look at those texts as documents and we stop looking at them as monuments, to use the classical distinction.

ADL: We see that one experience is like the experience for all. You know, if we go back some sixty years, and we had a book, an anthology, and we had one Muslim writer, one Christian writer, and one Jewish writer in that anthology. That's it: "Great! Representation for all three religions! Amazing!" And if we moved on about five years later, and then you'd have a Muslim woman, a Muslim man, a Jewish man, and you kind of break it down a little bit further, all these experiences are different. My experience as a woman is completely different to somebody else's experience as a woman. There are similarities, but it's about understanding nuances and the complexities of those identities as well.

JB: But also, I think it is a question of who gets left out.

CA: Yes, that's a difficult task to have to choose who's going to be included or left out. 
ADL: We got that with It's Not About the Burqa. And, spoiler alert: "It's not about the burqa" [laughter]. The surprising amount of people that have come to us and asked why there's not a single story about the burqa... and it literally says in the title that it's not about that. And so, suddenly, we were met by people who were not represented: these Muslim women that wear burqa, and it wasn't something that we consciously decided to do. There are also people that we approached who didn't want to be in the book. But, yeah, it's really a question of who is there and who is not, and it gets very critical, very quickly, rather than being just a text that comes out.

Elisabeth Massana: You've both mentioned history in your answers which ties really nicely to our next question because, when we were reading your texts, we realized that you both seem to be going back to different archives in your writing. Jay, for you it is national history, and the New Cross Fire in Surge (2019), or the literary canon and the Arthurian novels in The Red and Yellow Nothing (2016), and Afshan, for you it seems to be the personal archive in the shape of the scarves that you speak about in your text "The Hijabi (R)evolution" (2019). So, we wanted to ask you: what is the relationship between your writing and history?

JB: My work is very much tied to history, but I'm not a historian in any way, shape or form. I would discourage anyone from reading my work as history, even if it has a relationship to it. So, my first pamphlet is what I like to call a "queer-techno-Medieval misadventure". I took the story of Sir Morien, belonging to the Arthurian canon but from the Dutch canon, not the French, so we don't really have it in the UK. I was amazed by the black character in it and I thought "well, this is really interesting. I am going to take this and kind of do with it what I will", which is not history, that is not what history is [laughter]. I feel similarly with Surge, I went into a very specific archive and took a very specific historical moment but, ultimately, I offer an imaginative and highly personal treatment of it.

Somebody who really helped me with my "poetics" was a writer called Arlette Farge, who wrote a really interesting book called The Allure of the Archives (1989), in which she discussed what it meant to be going into the archives and to be working with them. And at one point she addresses people like myself who write "fictional" things and she says something to the effect of: "Without seeming snobbish, how can I say that when you come across a life in an archive, a fragment of a life, in a record or a document, that poetry and literature and fiction cannot do justice to these people's lives; the only way to do justice to these people's lives is by writing history". It's a tension I've grappled with ever since, because I know I don't agree with that statement, yet I think it's incredibly profound. I don't claim to bestow something as lofty as justice on the victims of the New Cross Fire. Indeed, that is a temptation I actively avoided. But talking about the fire, presenting my own exploration and interpretation of the 
archives is at least an introduction to that history for the many people who had never heard of it. I know this because people have literally told me that they had never heard of the fire until they heard me read a poem about it. No, I am not writing history, but does that make this small contribution to culture not worthwhile?

ADL: I used to hate history as a kid, because in the UK our education with history is really white. The only time that anyone not white might come into it was when we talked about the world war and about the revolt that Asian and Indian soldiers had because they had pig skin encased bullets or something... and that was it. And there was no other acknowledgement, we didn't exist in history. So, I was just questioning where we were and what our place was. And, in my family, we told quite a lot of stories and my father's a storyteller, his father's a storyteller, not professionally, but kind of sitting around and annoying all the kids by giving us long-winding stories like: "I had to walk 20 miles to school and you are moaning about walking 5 minutes"-stories. And, so yeah, for that reason I feel like I always go back to my history, I always go back to where I have come from. Maybe because I'm still trying to understand who I am. And I feel like I can know better who I am, knowing what I've been, what I am doing, and what I've done. But then writing began for me as a form of therapy, it began as a way of documenting my life as I was going along. And my very first fiction pieces were "diariesque" fictionalized entries. So, yeah, I feel like I always go back to what I know, and what I know is what I've been through, what I've done, and the people that I know, because I feel that all these stories are worth hearing, they are really interesting, and there is much in how you tell them.

CA: And there is a lot of truth in fiction, not in the sense of documental truth, it is, as you said, another kind of truth, that also needs to be brought into the historical discourse, because otherwise it would remain a very factual kind of account of the events of the past. If you think about Surge, there's all of the emotional components about the things that happened in history that also need to be preserved so as to have a complete historical record; obviously, that is not the only thing, but it needs to be there, in the way that it also speaks about... sorry, sorry, I was interrupting you.

EM: No, I was saying that with literature you seem to be able to shed a different light on history... And I'm thinking now -well I'm completely off script, sorry! - I'm thinking now about how The Red and Yellow Nothing is set in Medieval times and suddenly there is Kendrick Lamar there. For me there is a line that crosses history in a way that completely throws any understanding that we might have about how history has been built or told or written or received, which I think your texts do by opening new "lines of flight", sorry for getting Deleuzian here... 
ADL: I think it's moving away from $a$ history and towards histories, and understanding, acknowledging that actually there are lots of truths that can be known, but we are just doing it in slightly different ways. That's how I think of this.

CA: And you said "Deleuzian", but the reference that I had in mind was Sara Ahmed's idea of the need to go back to the past not nostalgically, not to repeat it, but to create new patterns on the ground, new ways of walking from there to here, which are not the trodden path.

JB: I think it's also what poetry is, isn't it? Right? A really simple device in poetry is juxtaposition, right? And I think just having one word next to another kind of does that.

CA: We have been talking about the more emotional, personal part of history, the lived experience of history and this links to the following question we want to ask you. The two words that came to us most often, while we were reading and in the conversations about your work, were "love" and "desire" which we felt - and we just wanted to confirm that with you - for both of you they were a tool, almost the ultimate tool for the redefinition of society. If that is the case, what would your definition of love be?

ADL: I write a lot about desire, desire in terms of lust, love, wanting to belong, this kind of yearning. And love comes within that, but we don't talk about lust enough. We don't talk about desire enough. We focus on this romantic notion of love that feels quite heteronormative; it goes like: "You will find this one person you will settle down with them and you will have kids, a dog, and a white-picket fence and that will be it". And I don't quite ascribe to that. I don't feel like that has any attraction for me. Desire for me is more freeing, more opening, more queer, and I'm able to explore different forms of it. And in terms of what my definition of love is, I did philosophy for my undergrad, and I know you can't tell by how... [laughter] it was a long time ago, it was a long, long time ago, and I spent it ... quite drunk actually... And one of the lectures that we did was called "LSD and GOD", and, well, we didn't take drugs, and it was love, sex, death, and god... I know, I know, I'm so disappointed when I tell that, because they were really boring lectures. But it was such a fun topic, because you're talking about love, sex, and death, you know, and god, and you can't really get any more... these are like first date questions. I studied love, I studied Plato, we studied all these different theories, and it was great, it was really fun, but at the same time it didn't really feel like what love is. For me, it was missing this idea of desire and lust. I mean, we kind of touched it a little bit, but not really. So, the collection that I'm writing at 
the moment is called Regarding Desire [re:desire, 2020], which revolves around how women of colour, or Asian women, for example, are supposed to be quite submissive and not to have a sexuality. So, what is it like for me to desire? Where does my desire fit into the world? What happens when I desire things that are not supposed to be desired? Another woman, for example, or another man, or both a man and a woman. What happens with that? And... I haven't told my mum yet. So, it will be quite interesting... [laughter].

JB: I think I have explored love more as an act of community than between individual people. And, certainly, an archive to me is an act of love. I work in an archive, so every week I go in and I do my best to be as respectful as I can to these histories. I work in a really weird archive, as well. So, when we go over the stuff I say: "Really? Are we really going to keep this? Ok, fine". Because it's important to someone, and it came from somewhere. And it's really not my job to make any decisions about that. And that actually links to a kind of readjustment in archival theory, which is "archival appraisal", and appraisal very simply means deciding whether something stays or goes. And recently in British politics and history we've had a very interesting case of this with the Windrush scandal that you've might have heard of, did that story make it here? $?^{2}$ In this particular context, I don't really think of love as a kind of attraction, but I think of it more as care and curation, and a long term view, as well. Someone decided to destroy those boarding cards -it was an extremely myopic decision that didn't take into account the shifting, arbitrary nature of immigration laws; it didn't

\footnotetext{
${ }^{2}$ In April 2018 it was publicly revealed that the UK Home Office had wrongly classified hundreds of people from the so-called Windrush generation as illegal immigrants, leading to the deportation of more than eighty of them to several countries in the Caribbean. People targeted by the Home Office and affected by the Windrush scandal were part of several waves of migration from the Caribbean that started with the arrival, in 1948, of the ship Empire Windrush. They had been granted full citizenship under the 1948 British Nationality Act, which guaranteed people who had come to Britain from the Caribbean imperial birth rights and the privileges and protections of full citizenship, including public benefits, employment, and the permanent right to remain in the country. As colonial subjects that had a legal right to live and work in the UK, they were neither required or given any documents upon entry. The classification as immigration offenders by the Home Office mainly affected citizens who had arrived as children and teenagers between the fifties and the seventies and were given indefinite leave to remain on arrival under the British Nationality Act, but could not provide documental proof thereof. Furthermore, it was later revealed that in 2010 the Home Office had destroyed thousands of landing card slips that recorded these arrivals when it closed its office in Croydon and moved to another site. As a result, most have lost their jobs, become homeless or been deported to countries they left as young children, forced to leave their families behind in the UK. See Gentleman (2019) for a full appraisal of the social and personal ramifications of the Windrush scandal.
} 
take into account the actual lives behind those legal documents; it was covert, dysfunctional, secretive, devastating. Love is often like that when it is channelled towards one person or one thing over another.

EM: We still don't have your book [Surge] but we have the edition which was out as a commemoration of the fiftieth anniversary of the...

\section{JB: George Padmore Institute? The New Beacon Books?}

EM: Exactly! And in your introduction, you mention Sara Ahmed, I think it's from The Cultural Politics of Emotion (2015). There, she speaks about love not as caring but as an excuse to, in the example that she gives, support white supremacists. So how do you negotiate these two different ways of approaching love, because one is about supporting community, and the other one is about destroying community.

JB: Yes, exactly. How do you approach that? The love of/for the oppressor.

ADL: That is quite interesting. So, when I started writing this collection, initially my first publisher had issues because I was writing about incest, and I was writing about love - cause that's a form of love, it's a form of desire that we don't talk about, and we don't talk about it for whatever reasons; but I feel that, by not talking about it, we've made it this whole kind of weird... people desire it for those reasons as well. So, it's about: "Well, let's talk about it in different ways" and how valid are the initial feelings of desire and love when they're about loving an oppressor, or loving hatred, or loving... and, in terms of incest, how does that work? I'm still answering that, so I can't give you an answer [laughter].

JB: Yes, and I think interrogation of human desires is kind of what poetry is, right? You sit there and you think "Oh, look at me writing this thing" and then it starts to become a poem once you recognise the strangeness of it, the contradictions, the assumptions behind each word.

ADL: And we're also queer people. Our desires are always interrogated, you know. Our sexuality is always being interrogated. It's never something that is just allowed to exist and be. So now that I am doing the interrogating, it's another form of control... [laughter]. 
JB: But on the other hand, you learn to interrogate all the things that you've learnt, that you're supposed to take as true. That's the beauty of being a queer person, right? You get to truly exist because you have thought about things, yourself, your culture. So many people never see their lives from the outside or recognise the truly fucked up practices that they are involved with and affected by. Nor do they see their privileges, I might add.

ADL: And now I have returned as well to describe all the things we didn't know when we were going through them. And it's certainly now that we go like: "Ah! That's what that thing was... That's what was happening!" And I have words for it, slang for it, and means that help us understand a little bit more about our lives than we did when we were actually going through them.

EM: Our next question has, in fact, to do with language... Jay, at some point you mention the concept "adjectival crisis" and, Afshan, you work with redefinitions of the concept "terrorist" in your play The Lesborrist Tapes, ${ }^{3}$ which I absolutely loved. We wanted to ask you what the nature of your work with the choice of words is, how you make language mean in dialogue with or in contrast to or generating resistance to mainstream usages of language. And also, what the role of orality in your writing is.

ADL: So, English is my second language and I didn't start speaking it till I was six, seven years old, still quite young, and at home we never even spoke it. So, when I started writing, I would have to translate from Urdu or Hindi into English to be able to write, which meant that a lot of the sayings and the words that would come out would make sense to me, because I understood where they came from, but in English they just sounded a bit dodgy. Instead of saying "third wheel”, I would say "There's a bone in the kabab", which made perfect sense to me, but it didn't make sense to other people. And then, yeah, exactly, "the bone in the what?" [laughter]. So, I realized that actually it's just another way of saying it; and there's a whole cultural history attached to it, too. So, I started using that a bit more: language mistakes being mistakes, and grammatical errors being grammatical errors, and redefining... So, the idea with terrorism for example is to "use terrorist": what does terrorist mean? What if a Muslim woman was to sexually terrorise someone rather than being violently terrorised...

\footnotetext{
${ }^{3}$ The Lesborrist Tapes, co-written together with Joshua Ferguson, was broadcast on Roundhouse Radio during LGBT History Month in 2013 and performed at the Edinburgh Fringe. An excerpt from the play is published under the pen name Tara Ali Din in the anthology Spoke: New Queer Voices (Lowe, 2015).
} 
where is the line between "violent terrorism" and "sexual terrorism"? And that's what I enjoy about looking at language. And I also speak a few different languages, not always very well. So, I end up only knowing a particular word or a feeling in a particular language and then, I am not able to translate it. So, I just end up using that word, because it's a lot easier for me than having to go to six different dictionaries to find the right one. And often there is no word exactly anyway and you end up just going back and forth, and it's very difficult to find that one word. And then you've got to put it into a poem and it just doesn't work at all.

JB: So, just to start at the "adjectival crisis" question, I realize we're at this interesting point in the UK where everyone is really struggling to describe what's happening. We don't have the language for it, even the people who think that they do. The word "Brexit" is a terrible word, it's a horrible conflation, and within it there are a set of concepts, desires, ideas, that, I think, are in many ways contradictory, in many ways aspirational, in many ways throwbacks. It's a euphemism parading as an explicit desire.

[Surge] was also influenced by Grenfell, ${ }^{4}$ and in some ways, I feel the incredible crisis of language was made visible by the reactions to it. I happened to be writing about the New Cross Fire at the time, so it felt like less of a crisis, because I had already read so much, seen so much language, around neglect, class, indifference...

But what [Afshan] just said about language is super interesting and, in the book, as you've probably heard, I use Jamaican Patois which for many, many years, I didn't even understand was a language, I didn't think of it that way... to me it just sounded like English with an accent, until I realised that syntactically and grammatically it is different. But something struck me the other day. I was talking to a friend who writes in Sanskrit, and she has these two huge Sanskrit dictionaries that she refers to. And she was like "This is my Bible", she goes back to them the whole time, and she's always

\footnotetext{
${ }^{4}$ On June 14th, 2017, a fire broke out in Grenfell Tower, a residential block of flats in North Kensington (London), which was part of Lancaster West, a housing estate built in the seventies to accommodate population displaced by slum clearances. The rapid-fire spread was a consequence of the unsafe and highly flammable exterior cladding installed during the 2015 refurbishing of the building. Seventy-two people died as a result of the fire, almost all of them racialized as non-white. The fire took place in the midst of Theresa May's immigration reforms aimed at the creation of a "hostile environment" for illegal immigrants that had direct consequences for both migrant populations and racialized British citizens (El-Enany, 2017). The colonial legacies of the Grenfell fire have been explored further by Nadine El-Enany, who has strongly defended that "Britain remains racially and colonially configured, a place where poor racialized descendants of colonized and enslaved people are made disproportionally vulnerable to premature death, as we saw in the Grenfell Tower fire" (2020: 34). The public inquiry on the fire is still in progress at the time of editing this text.
}

234

Lectora, 26 (2020): 223-246. ISSN: 1136-5781 D.O.I.: 10.1344/Lectora2020.26.24 
looking up words. I realized that my Patois doesn't have a dictionary, it's something that is deeply embedded...

ADL: You just know it...

JB: Exactly! And I thought "How do I know this?" When I'm trying to put together all these sentences, I don't think back to a dictionary, I think back to my mother in particular, and my dad speaking to me. And that was an interesting thing to notice. It's not an adjectival crisis, per se, but a profound recognition of something valuable that I thought I'd lost: traditional knowledge that marks me as someone specific, from a specific community, with a long history, that I'd mistakenly believed I'd lost.

ADL: In my household we speak English, Hindi, Urdu and bits of Konkani. There's no dictionary for that [laughter]. So, sometimes when my mum and I are having a conversation, we switch between different words in different languages without realizing we're doing it. But if we were to sit down, it would very difficult to work out the code: I've no idea how it works or the word order or anything, but it makes sense to both of us. When my sister tries it - and she speaks a lot of languages - she sometimes says it wrong, and we know that she's saying it wrong, so there's a right and wrong way of doing it, but I don't know what that is. And to define that, would just make it, I don't know... it feels a little bit, I'm not sure...

CA: There is a code to it, but you don't want to make it explicit...

ADL: Sure, I don't want to make it explicit. Plus, I don't know what it is! I haven't done work enough to be able to know what it is. And I'm sure that, you know, some of the words are the wrong translation, but that's the way, in our house, that's how we use them, and that's how we've come to...

JB: Because it's physical, right? I usually feel it in my body when I hear something and it's a bit off. Like if someone's doing Jafaican, ${ }^{5}$ I'll be like "eeewww!", because the physicality isn't there, nor the rhythm, nor the correct or appropriate phrasing. But then, when I try and speak Patois, I can only really do it in a literary context, or ironically, without sincerity. I can't actually engage with anyone, because I feel fake, wrong, and part of that is because physically I can't embody it; the way we would just

\footnotetext{
${ }^{5}$ Fake Jamaican.
} 
talk to each other [looking at Afshan], I can't do that. So, it is this weird thing, this disconnect between mind and body.

CA: But it's interesting as well, because then there are these words that either will never mean anything according to the dictionary, or they may mean something according to the dictionary, but to us mean something else because they're charged with personal history, with information about when I learned it, about the way my mother uses it... But then, translating that into poetry, I find that extraordinarily difficult, because it's not just simply inscribing a word in a context. It's making the context such that it makes that word mean in the way we need it to. And that is just so complicated. I was wondering if you've been struggling with that in your writing.

ADL: I did, I did for a long time, and I work with a lot of people who have English as a second language, and often they'll be really apologetic about the wrong word. But actually, it's not the wrong word, it's the right word for them at that moment, because I think that poetry doesn't have to fit through all the conventions. It doesn't have to be grammatically correct. And our meanings are... we give meanings to the words in that space. I don't know if you... sorry... It's a bit of philosophy. I really enjoyed reading Wittgenstein and his ideas about language games. This idea that, to put it in a nutshell, meaning is given by us. And there was another point to that, but I've just lost it, cause I've started to think about Wittgenstein, and it's so distracting. Oh! What was it? Oh, yes! When we're kids and we're reading novels, and we come across a word we don't necessarily understand. I wonder if you actually tried to find a dictionary to find out what that word meant. Ok, fine. Cause I didn't. I was really lazy. So, I'd just skip over the word and pretend I understood what it meant, and then it would make sense later. You know, I'm pretty sure... I can see somebody agreeing... Come on! I can see some of you go "yeah". You've done that. Great! Because we even have dictionaries in our phones now, but none of us do that. So, we just skip that word, pretending that we know what it means, and then come back to it. But certainly, when it's a word in a different language, everyone wants to know what the translation is, and I'm like "come on", you know. There are so many words that I still don't understand in English, but, you know, I still, I won't go to a dictionary, so why can't we just move past this word and pretend that it's whatever it is.

CA: Yeah, that's what Gloria Anzaldúa asks us to do in Borderlands/La Frontera (1987), right? That mixing of languages that renders the text untranslatable... That's interesting.

Just to go to the next question. This one's for you Jay. And it's something that we have already talked about briefly, but I'd like to spend a little bit more time on it. We 
both, Elisabeth and I, understood Surge to be rooted in the tension between Thatcher's favourite statement: "There's no society. There are only individuals", and the inscription of "shared life", love ties, and community. If that is so, how did you conceive your work in dialogue with said tension between the uniqueness of the individual's existence and the community. How does that work for you?

JB: I actually think that I'm kind of coming from a slightly different angle. When Thatcher said "There's no such thing as society" she was disavowing the idea that anyone had any commitment to anyone else. This has been borne out by the social policies of the 80s and 90s, and in fact the 2000s - stripping public assets, eroding communities, commodification of housing, militarisation of the police, austerity. But the quotation I really work with is one that she said in 1978. She said: "People are really rather afraid that this country might be rather swamped by people with a different culture. People are going to react and be rather hostile to those coming in" ${ }^{6}$ That's the language of degradation, that's the language of people as rats, people as cockroaches, people as fleas, people as dirty, as contaminants. This is the language you use to dehumanize, right? And then you justify that dehumanization in this kind of logical loop, by saying, as she does, that people are going to be rather hostile. In other words, she's turned Black people, and Asian people, and migrants, into this thing that needs to be met with violence. And that speech became the name of a police operation called "SWAMP 81", which came after the protests around the New Cross fire in central London. And obviously people felt that it was incredibly insulting, to call a police operation after a racist speech that the Prime Minister gave. Nearly a thousand people were stopped and searched in the course of two or three days in a particular area of London called Brixton. And that is what sparked the Brixton riots in 1981, because they were trying to arrest somebody who'd been stabbed, or they had been trying to take him away and the crowd refused to let him be taken away, and then it all escalated from there.

So, when we're talking about communities, it is super interesting to see how the Premier, a major political figure, can create that through language, by giving this speech, by giving this dog whistle that entitles one community to attack another. It's a very old tactic. There is no such thing as society, except when you want people to gang up against others. But what's interesting to me is that, when you go to Brixton, for example, and then you see communities thriving, no one has any problem, right? Everyone's fine. People are living their lives, in their houses, feeding their children, doing whatever. And it's only when you create this tension that things fall apart, right?

\footnotetext{
${ }^{6}$ Thatcher's statement was given in a 1978 interview in the Grenada TV programme World in Action. The interview took place in the context of the 1979 political election, where immigration and race where brought to the forefront of the political debate.
} 
When you blame people's economic, social and cultural frustrations on their neighbours, rather than central government or the actual elite who govern the country and pass so many harmful policies. Because it's a kind of production - you need to produce violence. It's something you use to give you some credibility as a politician and also to get through a particular vote, for example. It's a tool that's always used -if you want to get attention, attack migrants or gays or people on benefits. Vulnerable groups. People always fall for it, because the language of invasion and infection is powerful. But then, when you go back to community history, you also see how there is always resistance. I think it's important to pay attention to how language can degrade, and how it can destroy things that would naturally come together.

CA: In relation to this, the image that comes to me from your poetry is this description of this photograph of a coffin I think it is, and the person who stands describing himself in that picture, and says that, for some reason, they've enlarged it to only show his -I think it's a "he" - his face, but he says he remembers the people standing next to him and the links that united him with those people...

And that was the way I read everything that you were doing in Surge, which was, for every single individual death, bringing in the whole story, all of the love that surrounded that person, which again ties with what we were saying, about the political motivations behind the writing.

JB: Exactly! You could really believe the unrest was started by Bad People, who were nothing but Bad and simply had Bad Intentions.

ADL: It was done by a bad person, Thatcher, you know? She started it... [laughter].

EM: So, our next question is for you, Afshan. In the introduction to It's Not About the Burqa there's a text by Mona Eltahawy, who was here in Barcelona recently, I hope everybody got to see her, and she defines "the female Muslim body as a proxy battle field" (2019: 4), caught between Western Islamophobia and Muslim's misogyny. And we wanted to ask you how you conceive the female body in your writing and also in your activism.

ADL: See, I write about the female body quite a lot. I write about desire quite a lot. And the female body is very pretty. So, clearly, I have to write about it. For me, as I was a hijabi, so I've been wearing the headscarves since I was six years old and all out of choice, always my choice, I had massive arguments with my parents about it... And what I found very interesting is both when I wore it and when I didn't wear it, it would always become a point of conversation for other people. So, it's never a conversation 
about me/with me. There's always somebody else having an opinion about me. There's an opinion about me when I wear it, there's an opinion about me when I don't wear it. People in my community have an opinion of why I wear it or not wear it. She's right [Eltahawy], isn't she? There is always a battle going one about/on our bodies...

And one of the biggest difficulties I've had with my own writing is precisely writing about misogyny in Muslim communities or in South-Asian communities knowing full well that anybody could pick up that writing. And in the UK right now South-Asian men, Muslim men are facing a lot of racism, lots of Islamophobia. And when I'm writing about this misogyny, I think it's therapeutic for me and it's also therapeutic for the other women who are facing it and it needs to be talked about, so we can reach a solution. But it often gets used as racism, it gets used for fuel for racism or Islamophobia. So, I have this kind of internal battle constantly, where I don't want to talk about the misogyny in my community. Should I just ignore it so that it doesn't get used for racism? And it's really difficult, and I still haven't found... I still haven't worked it out, because I feel like I live my life as an activist, and I do a lot of support work helping particularly young black men, young people of colour to know their rights when they're being stopped and searched in the UK. And, working with young people, particularly, you should try and get them out of their comfort zones and really engage with stuff. I feel I do a lot of activism and I'm a queer Muslim woman, and on many different levels I have to be active about what I do, otherwise I wouldn't be able to survive. And I feel like it's often a privilege for a lot of people to not have to think about being an activist, or just even not be an activist, because for me every day is like a protest, just walking into a room and by the nature of existing, I'm already protesting many things. People have told me that. It's really weird to kind of be like: "Hi! I'm Afshan, I'm queer Muslim and I protest" at the same time, because you know, I have that added to my bio. Yes, I'm all right with that lot, because I feel like the battle I'm facing is an interesting battle, and writing is how I get to the solution. Oh, you know, sometimes it just confuses the heck out of me.

CA: Actually, the last question before we open it up to the floor is for both of you and, in fact, it's a question you've been somehow answering already. How do you reconcile your activism and your writing? How do those two things come together when the search for an individual literary voice and the activism that you engage in is so much based in the building of a communal voice?

ADL: There's this weird notion in the UK and maybe here as well... I think actually in the West in general, that if you write for activist purposes, then your writing quality isn't as good because you're writing from identity and for political reasons. So, political writing or writing from political identity is not as good as "literature" [laughter]. And often literature is a white dead man that maybe nobody reads any 
more, and we are forced to read in schools. So, I like to challenge that by trying to write stuff that is quite literary but that is quite activist, too. And again, because of my nature, being who I am, just by having a queer character or a Muslim character, and/or both in the stuff that I'm writing, it becomes an activist concern in and of itself and that's it. And if I choose not to write about identity, that is also a form of activism for me, because there's also this idea that I have to be writing about being a Muslim, I'm supposed to be writing about all of the traits in my identity. If I don't write about that, that means also a form of activism. So, I feel that my writing and my activism are really tied quite closely in what I do, I cannot do both of them or either of them. They have to exist at the same time. And funny enough, neither of them pays very well [laughter]. So, if there is anybody here trying to be an activist and/or a writer... spoiler alert!

JB: I think I have tried to embrace the term "cultural activism", problematic as it might be, because for a very long time I've been trying to find or articulate the space that I sit in. Mostly my concerns are cultural, not strictly political although of course the two are entwined, so I see myself very much as a cultural activist. I'm a film programmer as well, so it's literally my job to decide what people will see, what is put on the screen. I think I take that really, really seriously... And then there is something about working in the archive as well, that to me indicated a shift that I think was really, really necessary, and maybe by just saying what that is, it will become obvious why I say that: but as I was working, spending more and more time at work, I realised that I was finding it to be a bit of a queer space, and that actually tons of queer people work in archives now, and perhaps it was ever thus. It's something that has built up over the years. I think it has become a place that may be different from the original location of queer people, which was once in the closet or prison or a mental institution, and then the night club, and now I feel like it's becoming the archive, and it's becoming a powerful cultural space. To me that is what activism is, it's taking care of your history, and it's preservation, it's appraisal, it's all of these little decisions that you make that create something that can be passed on. And so, political activism is important, don't get me wrong, but I see myself more as a custodian, you know. I would so much rather be folding a flag up and putting it in a nice box to make sure it's there...

CA: That's nice. We could go on forever, but we wouldn't want to monopolize your time. So, if anybody from the audience wants to raise any questions, any comments...

Q1: When it comes to queer identity, I feel like there's always a process of figuring it out, and that fiction, literature, writing, and art can play a big role when it comes to figuring out who you are, where you stand. And I just wanted to ask if, when you were figuring it out yourselves, there were any authors that helped you. I also wanted to 
know if the process of writing helped you learn things about yourselves that maybe you didn't know because there's really not a lot of content yet for people to consume, to see themselves in when they are queer, and especially queer people of colour. That is why what you are doing is fantastic because people will be able to see themselves in your writing, but that has not always been the case. So, I was wondering if there was anything that influenced you or helped you in that sense.

ADL: So, growing up for me, I didn't realize I was queer until somebody said the word "bisexual" and "queer", and I was like, "Oh! That's what I am". It felt so great [laughter]. And I just thought it was a general thing, I thought "everybody fancies everybody... Come on, we're sexual people. That's how things work". And to me, when I was growing up, it was more about trying to find books that reflected me. And I remember distinctly finding Malorie Blackman and Bali Rai, children's authors and both amazing... and then finding Darren Shan. And I picked up Darren Shan because I thought it was Darren Shah, and Shah is quite an Indian name. So, I was really disappointed when I read through it and I realised there were no people of colour in the book. So, I put that away [laughter]. My first experience seeing a queer person of colour, a queer Muslim person actually for me, 'cause that's what I needed to identify with myself, was in Contact Theatre in Manchester; they have this poem that was written on a staircase, and the poet was Qasim Riza Shaheen, who at the time was doing a show as a Muslim Drag Queen, and it just blew my mind because not only was it a Muslim poem in a theatre, but it was a gay Muslim poem in a theatre, who also had a show on in the theatre. And I was just like "Wow! This is way too much for you right now". And so, I held on to that. And then I made a lot of friends, and I met a lot of queer people, Muslim people, and I built my community, and we were mainly authors who needed a way to express ourselves, and build, and represent in a way that is helpful to the younger generations, and open up that conversation. And in fact, it's the one thing that my mum understands as well. So when I had a conversation about my sexuality with her, which she didn't quite get to begin with, I told her: "Well, if my existing or me being out there and being proud about who I am allows someone younger to see themselves in me, and feel like they have a reason or they're allowed to exist, then I've done my job". There's nothing worse than not seeing yourself reflected, and seeing yourself as a monster. And that's what I'm doing. I'm reflecting.

JB: There are so many things that I consumed as a younger person to help me find out... literally, there's a huge list, and I can't say everything, but I think, film wise, for me two of the most important films... well, in fact, three, three. I'll take two! [laughter]. The first one was The Watermelon Woman by Cheryl Dunye, which is about a black lesbian who goes into the archive and finds a story about... [laughter] and I was like "Oh! Shit! That's amazing!" It's really like negro film noir. And the 
second one is Go Fish which, again, just looks into all the kind of problems, the political stuff of the time. And I watched both of these when I was maybe 15 or 16, when it was super important for me. And then in terms of poetry, I was really lucky as well... I started quite young and I had lots of friends who were already poets and there are three names who were really important to me when I was younger, and that's Jackie Kay, the Scottish Makar, Dorothea Smartt, a black poet, Aoife Mannix, a queer performer poet who was one of my favourite poets at the time... Literally I could go on and on, but I think these might be the most influential ones in my very, very early life...

ADL: Dorothea Smartt taught me gravitas..., you know, and I never... she just has such grace when she does her poetry and I have none of... If you don't know Dorothea Smartt you need to google her...

Q2: I have a question for you, Afshan. I was reflecting on your poem about your mother's mother tongue, and I was linking it to an event which took place last Thursday in the Festival "Barcelona Poesia". An Asian poet called Sujata Bhatt came, and she talked about her fear of losing her mother tongue, which was Hindi, I believe, when she migrated to the United States. So, I wanted to ask you if this particular poem you have read to us, reflects some kind of fear of losing your mother tongue...

ADL: So, I used to think in Urdu and Hindi. I used to dream in Urdu and Hindi, and I don't know how I know that, but I remember distinctly waking up one day when I was eleven-twelve and going "Oh, my God! That was an English dream!" And then it happened more and more to the point that now I think mainly in English. And that's really scary, because when I'm speaking Urdu or Hindi, and even Konkani, which I'm relearning, my tongue hurts from speaking it, because I'm not used to saying those words, you know. I can't talk about theory in Hindi. I can't talk about Wittgenstein in Hindi, because I don't know the word for language games. Is there a particular term? Who knows? I can't talk about philosophy in that way. And that's really scary, because I want to be able to do so... our theory stopped, and my understanding of that stopped, as well. So, yeah, there is that fear, and it's very real. But I try and get over it by having as much conversations as I can in as many languages I can when I go to visit my parents, my grandparents, and I'll say it all wrong, it will be all the wrong grammar and the wrong words, and it's fine because I'm trying to cling on to something that I don't want to lose. And we're almost forced to speak English. Everything is in English. Even here most things are in English as well. So, it's this scary notion that, you know, the wiping off of this entire existence. And I find it when I'm speaking Urdu, when I'm speaking Hindi, there's a way I will sit, there's particular mannerisms I'll take on, 
my hands will move in different ways. There's just a different way that my body will use that language. And there're different things that I will say, and I'll be slightly funnier or sexier in different ways. And to lose all of that is really sad. Sorry, it's taking it a bit deep, isn't it? Yeah, it's really sad. So, if you speak anything aside from English, please cling on to it, and teach your kids, as much as they'll hate it.

\section{CA: Any other questions?}

Q3: Thanks so much for your poetry, it was really moving... Afshan, you were talking about this internal battle that you feel when you write about homophobia in your own culture, and thinking that maybe while you are doing this, you may be betraying your community. And this was making me think of Hannah Arendt, who wrote about Jewish people in a very thorny moment. She was very critical of Jewish people during and after the Holocaust, and because of that she was stateless for eighteen years. And I was thinking about this notion of "statelessness", and I was wondering if we could maybe think of queerness in a way as being stateless or, rather, as generating a different form of state. And here I'm thinking of Sara Ahmed's disorientation. And I think this is actually a question for both of you. What is your take on "queer"? Is that a form of community? What are your feelings on the "state"? Because, Jay, you describe yourself as black British, right? And so, what is your take on the UK. Would you say you embrace that identity? Do you feel that Britain is home? I'm sorry. I'm not sure if this makes sense.

ADL: No, no. It does. I hear you, I hear what you are saying... I think it's often very difficult for us to be critical of anything when we're being attacked. So, we become acritical of ourselves or of our people when we are being attacked by anything. And that's kind of what I was sort of talking about by not talking about homophobia, for example, in the community, and misogyny in the community, because I don't want... when I'm at battlefield, that doesn't matter. What matters is protecting [hesitates] "my people"... that sounds horrible... [laughter]. You know, protecting people, and that's what I want to do. If I'm faced with racism, I will defend. If someone comes up at my brother, I will defend. When we are alone in my house, I'll beat the shit out of him [laughter]. You know what I mean? It is that kind of protectiveness that we feel. And in some ways, it's really great, but in other ways it can be detrimental, because we don't progress anymore, because we don't actively have these conversations when we need to be having these conversations. And then the second question is about the word "queer". I love the word "queer" because, for me, it's a political identity, as well as a sexual identity. And it's a word that doesn't have the word "sexual" in it, which "bisexual" does. And I want to be able to talk about sexuality without talking about 
"sex" because they are two different things, and they often get confused quite a lot. There's a lot of debates happening right know in the UK about education in schools, and there's a lot of Muslim parents that have protested against LGBTQ relations being "taught" at schools. And that's a really difficult conversation happening right now, and it's because they see sex and sexuality as the same thing, and also, they're really homophobic. So, how do I then challenge that? How do I tell these homophobes to fuck off, because I don't want them to enter the room? If I do, what will happen? The moment I start telling the Muslim parents that they are being homophobic, who's behind me? It's usually white gay men that are really Islamophobic, and they'll be like "Yeah, you Muslims are..." and I will be like "No, no, I don't want to do this". And I feel queer, so my body is all of that for me, and it crosses cultures, it crosses generations and, it's a word that I identify with more than with "gay" or "lesbian" or "bi".

JB: I mean, I think there's so much in the question [laughter]. It's a really lovely question, because it does get at those of us with hyphenated identities or experiences. For me the Black is the status bit and the British bit is the condition in which I live. On the one hand, I obviously resist and am critical to the kind of history that brought me to Britain, but equally I recognise I'm extraordinarily privileged now as a result of that quirk of history. And that's now being threatened in a way that I didn't even understand to be important to me with the Brexit vote, with withdrawal from the European Union, when we now see the resurgence of this ugly fascism in our context that we thought that had been extinguished completely. So, it's a bit of a crisis now to me because I often think, where would I go? Where in the world could I possibly exist in my current state? Maybe New York? But then, I'd still live in America, right? [laughter]. But I think also with the term "queer", I love the term "queer" and I grew up with the term "queer", and I've always used it as orientation and gender identity, actually. But I also think that "queer" is a term that is rapidly losing its political significance in many ways, and that's to do with a tide of homonationalism and pinkwashing which co-opts queerness for nationalistic ends. We see an echo of that in big companies and corporations participating in pride parades and things like this. I think we are, in Britain, in much of Europe, in the same position as anybody else who has to think critically about what it means to live in a particular state, and particularly one as rich and historically belligerent as the UK. It's an incredibly rich question... but I can only talk for a bit! [laughter].

ADL: With queerness as well we need to talk about home and family more. And I don't necessarily mean the family as the people you are blood related to, but the family you create, and the home and community that you create. And for me that's the biggest supportive network. So, I have a queer family. I have my family-family and then my queer family. So, when I think about where I am in terms of queer identity 
and about where my home is, I think it is with both of those people. And with both of those sets of people, queerness crosses everything. Racists love to say things like "Go back home to where you came from", right? But, what is home? India and Pakistan, literally, are still at war with each other right now. I can't go to either of those places. I was born in Dubai, and Dubai is not ever going to give me citizenship, so I'm kind of stuck in this, in the sea, between these three different places and the UK, and no one will take me, and I don't know...

JB: Go to New York.

ADL: Maybe if Trump leaves, then I might think about it. I may come to Barcelona. Who knows? But I've heard that Fascism is on the rise here as well. So...

JB: In all of Europe.

CA: Thank you so much for your generosity with your ideas and thoughts, for everything you have shared with us. Thank you from all of us here today.

\section{WORKS CITED}

Ahmed, Sara (2015), The Cultural Politics of Emotion, New York, Routledge.

Anzaldúa, Gloria (1987), Borderlands/La Frontera, San Francisco, Aunt Lute Books. Asghar, Fatimah and Safia Elhillo (eds.) (2019), Halal If You Hear Me: The BreakBeat Poets, Vol. 3, Chicago, Haymarket Books.

Bernard, Jay (2016), The Red and Yellow Nothing, London, Ink Sweat \& Tears Press. -(2019), Surge, London, Chatto \& Windus.

Bernard, Jay and Ruth Bush (2016), Beacon of Hope: New Beacon in Poetry and

Prose, London, New Beacon Books \& George Padmore Institute.

Bryan, Beverley, Stella Dadzie and Suzanne Scafe (1985), Heart of The Race: Black

Women's Lives in Britain, London, Virago Press.

Busby, Margaret (ed.) (1992), Daughters of Africa, New York, Ballantine Books.

-(ed.) (2019), New Daughters of Africa, Oxford, Amistad.

D'souza-Lodhi, Afshan (2019), "Hijabi (R)evolution", It's Not About the Burqa,

Mariam Khan (ed.), London, Picador: 115-125.

-(2020), [re: desire], Portishead, Burning Eye Books. 
El-Enany, Nadine (2017), "The Colonial Logic of Grenfell”, Verso Books Blog, 03/07/2017. <https://www.versobooks.com/blogs/3306-the-colonial-logic-of-gre nfell>

-(2020), (B)ordering Britain: Law, Race and Empire, Manchester, Manchester UP. Eltahawy, Mona (2019), “Too Loud, Swears Too Much and Goes Too Far”, It's Not About the Burqa, Mariam Khan (ed.), London, Picador: 3-9.

Farge, Arlette (2013), The Allure of the Archives, New Haven \& London, Yale UP. [1989]

Gentleman, Amelia (2019), The Windrush Betrayal: Exposing the Hostile Environment, London, Guardian Faber Publishing.

Khan, Mariam (ed.) (2019), It's Not About the Burqa, London, Picador.

Lowe, Adam (ed.) (2015), Spoke: New Queer Voices, Batley, Dog Horn Publishing.

Shukla, Nikesh (ed.) (2016), The Good Immigrant, London, Unbound.

Shukla, Nikesh and Chimene Suleyman (eds.) (2019), The Good Immigrant USA: 26 Writers Reflect on America, London, Dialogue Books.

Soto, Christopher (ed.) (2018), Nepantla: An Anthology for Queer Poets of Color, New York, Nightboat Books.

Walter, Aubrey (1987), Tongues Untied, London, Gay Men's Press. 